
\title{
3 Researchspuare \\ Detection of Aspergillus Flavus in Wheat Grains Using Anti-Mannoprotein (MP1) and Spore Proteins Polyclonal Antibodies
}

\author{
Ranjana Kumari \\ Indian Institute of Technology Kharagpur \\ Ananta Ghosh ( $\sim$ aghosh@bt.iitkgp.ac.in ) \\ Indian Institute of Technology Kharagpur https://orcid.org/0000-0001-5851-8118
}

\section{Research Article}

Keywords: Aspergillus flavus, mannoprotein (MP1), cloning and expression, polyclonal antibody, ELISA

Posted Date: May 27th, 2021

DOl: https://doi.org/10.21203/rs.3.rs-530983/v1

License: (c) (1) This work is licensed under a Creative Commons Attribution 4.0 International License.

Read Full License

Version of Record: A version of this preprint was published at Applied Biochemistry and Biotechnology on January 11th, 2022. See the published version at https://doi.org/10.1007/s12010-021-03780-w. 


\section{Abstract}

Cell wall mannoprotein (MP1) gene of an aflatoxigenic strain of Aspergillus flavus, isolated from stored wheat grains, was cloned and sequenced. MP1 protein was expressed in E. coli in soluble form and purified. Polyclonal antibodies were raised against recombinant MP1 protein and inactivated spores of this fungus in rabbit, and purified by ammonium sulphate precipitation, Protein A sepharose and antigen affinity chromatography. The minimum concentration of purified mycelial or spore proteins that could be detected by ELISA was determined as $100 \mathrm{ng}$ using $2 \mu \mathrm{g}$ of these antibodies. The anti-MP1 antibody was found more sensitive than anti-spore protein antibody. Western blot and immunofluorescence analysis showed reactivity of these antibodies to various proteins ( $30 \mathrm{kDa}$ to $200 \mathrm{kDa}$ ) distributed throughout the surface of mycelia and spore of $A$. flavus. Cross reactivity of these antibodies was detected with fungi belonging to different Aspergillus, Rhizopus and Alternaria species out of fourteen different fungal species tested. In fungal contaminated wheat grains these antibodies could detect presence of as low as $1 \mu \mathrm{g}$ mycelia or $10^{3}$ spores per gram of wheat grains using ELISA. The results suggest that the developed antibodies could be successfully applied for the detection of predominant fungal infestation in stored wheat grains.

\section{Introduction}

Fungal infestation in stored food grains can cause loss of seed germination capacity, nutritional values, viability, decolouration and foul smell leading to huge economical loss [1]. Eurotium and Aspergillus are the most common fungi causing grain spoilage during storage [2]. These contaminants are mainly present in the form of spores, and with the increase of water activity and temperature geminate to spread infection [3]. Spores can survive for long term in adverse physiological and environmental conditions that is a key attribute for fungal reproduction, persistence, and dispersal [4]. Fungi belong to Aspergillus produce a variety of mycotoxins which may lead to refusal of stored food grains $[5,6]$. Aspergillus flavus can also cause aspergillosis in immune-compromised individuals [7]. Therefore, determination of the mycological contamination of stored grains is very important as it is destined to be used as food and animal feeds. Several direct methods like dilution plating, measurement of volatile compounds, evaluation of ergosterol and chitin level, next-generation sequencing (NGS), and indirect methods like randomly amplified polymorphic DNA (RAPD) analysis, amplified ribosomal DNA restriction analysis (ARDRA) and denaturing gradient gel electrophoresis (DGGE) have been developed for the detection of fungi infestation. However, numerous disadvantages are associated with these techniques. These methods are time consuming, labour intensive and require mycological expertise [8]. Also, it is difficult to distinguish accurately among the infested fungal species or to yield quantitative data [9]. As a consequence, there is a need to develop new reliable method that will be highly specific, relatively rapid, inexpensive, and reproducible. Immunological technique based on antigen and antibody interactions offers such an alternative. Immunological method such as enzyme linked immunosorbent assay (ELISA) has been developed for the serological detection of mold infection in patients, as well as detection of fungal contaminants in grains like rice, wheat, and barley $[10,11,12]$. Notermans et al $[13,14]$ have 
developed ELISA for the detection of different Penicillium, Aspergillus, Fusarium, Penicillium fungal species in cereals, fruits, fruit juices, and spices. These immunological methods have some limitations as it showed cross reactivity with the closely related fungi at species, genus and family level. Antibody developed against $A$. flavus mannoprotein (MP1) protein has been used for the detection of aspergillosis in immune compromised patients [15]. In addition, different fungal materials such as mycelial homogenate and extracellular polysaccharide also have been used as antigens for the production of antibodies to detect fungal infection but no study has been done using fungal spores, although spores would have been used as suitable antigen for the production of antibodies for immunological detection of fungal contaminants in stored grains. Here, we report production of polyclonal antibodies against MP1 and spore proteins of a recently isolated aflatoxigenic $A$. flavus isolated from stored wheat grains, and its use for the detection of fungal infestation by ELISA.

\section{Materials And Methods}

\section{Fungal culture and maintenance}

All the fungal strains used in current study has been previously isolated from stored wheat grain and identified based on sequence analysis of ITS region [16]. ITS sequence of all the fungal strain has been submitted in GenBank database. Aspergillus flavus (SW18 |KY260662|), Aspergillus niger (SW14 |KY065351|), Aspergillus candidus (SW140 |KY260674|), Aspergillus sydowii (SW95 |KY065362|), Eurotium amstelodami (SW173 |KY260676|), Rhizopus oryzae (SW1 |KY260656|), Rhizopus microspores (SWC8 |KY260682|), Alternaria alternate (SW90 |KY065361|), Penicillium cinnamopurpureum (SW13 |KY065350|), Talaromyces islandicus (SW101 |KY065363|), Myceliophthora verrucose (SW89 |KY065360|), Syncephalastrum racemosum (SWC18 |KY065367|), Westerdykella globosa (SWC6 |KY260681|) and Mucor circinelloides (SWC9 |KY065371|). The pure cultures were maintained on potato dextrose agar media at $28{ }^{\circ} \mathrm{C}$.

\section{Spore collection and inactivation}

The isolated Aspergillus flavus was cultured on coconut agar media ( $100 \mathrm{ml}$ coconut milk and $2 \%$ agar) for 7 days at $28{ }^{\circ} \mathrm{C}$. The spores were collected in PBS containing $0.1 \%$ tween 80 and washed three times by centrifugation using PBS. It was then inactivated by keeping in $4 \%$ formaldehyde solution, for 5 days at $4{ }^{\circ} \mathrm{C}$ and then washed several times with PBS. The inactivation was tested by culturing inactivated spores on PDA media for 7 days at $28^{\circ} \mathrm{C}$. The spore density was determined by haemocytometer under the microscope. and the protein content was measured by the method of Bradford using BSA as standard [17].

\section{Extraction of proteins from fungal mycelia and spores}

After the removal of spores from the culture plate containing full grown A. flavus (described above) fungal mycelia were collected by scraping the top of media with the help of sterile spatula. The collected mycelia and spores were washed thrice with PBS and then crushed in a motor using pestle in presence of 
liquid $\mathrm{N}_{2}$. The powders of mycelia and spores were dissolved in PBS ( $\left.\mathrm{pH} 7.4\right)$ containing protease inhibitor cocktail ( $5 \mu \mathrm{l} / \mathrm{ml}$ ) (Sigma), $0.05 \%$ of tween $20,50 \mathrm{mM}$ DTT, $0.3 \mathrm{U}$ chitinase and $0.2 \mathrm{U} \beta-1,3$ glucanase. Thereafter, $0.3 \mathrm{~g}$ glass beads (Sigma) was added, vortexed for $5 \mathrm{~min}$ in bead beater, sonicated for $5 \mathrm{~min}$ and kept at $37^{\circ} \mathrm{C}$ for $2 \mathrm{~h}$ for complete lysis. The lysates were centrifugation at $20,000 \mathrm{x} \mathrm{g}$ for 20 min and the supernatants were collected. The protein content of the supernatant was measured by the method of Bradford [17].

\section{Cloning of Aspergillus flavus MP1 gene}

Total RNA was extracted from A. flavus mycelia using TRIzol and cDNA was synthesized from the isolated RNA using cDNA synthesis kit and adaptor primer (5'-

GGCCACGCGTCGACTTTTTTTTTTTTTTTTTT-3') as per manufacturer's protocol (Thermo Scientific). MP1 gene was amplified form the cDNA using gene specific primers (MP1F-5'-GCGCCTCGATGGGAGAAAG-3' and MP1R-5' GACTATAGCAAATTTCAAACGCGG-3'). Amplified MP1 gene was cloned in pTZ57R/T vector (Thermo Scientific), transformed into chemically competent Top10 Escherichia coli, and sequenced using Big dye (Thermo scientific) in an automated DNA sequencer (ABI 3500). Homology search of the obtained sequence was done using BLAST.

\section{Expression of recombinant MP1 in E. coli and purification}

The entire open reading frame (ORF) of MP1 gene (822bp) was amplified from pTZ57R/T-MP1 by PCR using forward primer (5'-GTCAAGGGATCCATGAGATTCTCCGCTATCT

TCACC-3') containing BamH1 restriction site (bold) and reverse primer (5'-

CATCGCCCCGGGTTAGACAGCGACGGCAATGGC-3') containing Xma1 restriction site (bold), and cloned into the BamH1 and Xma1 digested bacterial expression vector pGEX-4T-3 (GE Healthcare) in frame with GST-tag at the N-terminus. MP1 gene was also amplified using another primer set [forward primer, 5'TCCCGTCCATATGAGATTCTCCGC-3' containing Nde1 restriction site (bold) and reverse primer 5'GAGGTTCTCGAGTTAGACAGCGAC-3' containing Xho1 restriction site (bold) and cloned into pET28a vector in frame with $6 x$ His tag at the c-terminus. Both the plasmids were transformed in to chemically competent $E$. coli and protein expression was achieved by induction with $1 \mathrm{mM} \mathrm{IPTG}$ at $16{ }^{\circ} \mathrm{C}$ for overnight. The GST-tagged fusion protein and His-tagged fusion protein were purified through glutathione sepharose 4B and Ni-NTA affinity chromatography (GE Healthcare), respectively. Expression of GSTtagged and His-tagged recombinant MP1 proteins were confirmed by western blot analysis using antiGST and anti-His antibody (Sigma), respectively. Since, the western blot analysis of GST-tagged MP1 protein showed multiple bands, further purification was done through Q-Sepharose anion exchange chromatography, and eluted from the column using a gradient of $0-2 \mathrm{M} \mathrm{NaCl}$. The proteins present in peak fractions were collected, desalted and concentrated by centrifuging through YM 50 centricon column (Millipore). The quantity of purified proteins was determined by the method of Bradford [17] and quality was checked by SDS-PAGE.

Production and purification polyclonal antibodies 
Polyclonal antibodies were raised in New Zealand white male rabbits following the method of Harlow and Lane [18]. In brief, $500 \mu \mathrm{g}$ of GST-tagged MP1 protein and inactivated spore were separately mixed with Freund's complete adjuvant and injected subcutaneously in two different rabbits. Five more booster administrations were given using the same amounts of antigens via same route but mixing with incomplete Freund's adjuvant. Blood was collected 14 days after the final booster, serum prepared and the titer of the antibody was checked by the direct ELISA using the same injected antigen. The immunoglobulins were separated from the sera by $50 \%$ ammonium sulphate precipitation, dialyzed against PBS to remove salts, and IgG was purified by protein A sepharose affinity chromatography. Further purification of antibodies was done by antigen (MP1 or spore protein) affinity chromatography. For antigen affinity chromatography, recombinant His-tagged MP1 protein and spore lysate was coupled separately with cyanogen bromide activated sepharose 4B (GE healthcare) as per manufacturer's protocol. Protein A sepharose purified IgG was loaded into these columns, washed with PBS to remove non-specifically bound antibodies and antigen bound specific antibodies were eluted using $0.1 \mathrm{M}$ glycine buffer ( $\mathrm{pH}$ 2.5). Eluted antibodies were immediately neutralized by adding $1 \mathrm{M}$ Tris $\mathrm{pH} 9.0$, desalted using centricon YM50 (Millipore). Concentration of antibody was determined by the method of Bradford [17] and quality was checked by $10 \%$ SDS-PAGE.

\section{Enzyme linked immunosorbent assay (ELISA)}

Standard direct ELISA was used for determining sensitivity of purified anti-MP1 or anti-spore protein antibodies. Assays were performed using varying amount of antigen (mycelial / spore / recombinant MP1 protein) ranging from $100 \mu \mathrm{g}$ to $100 \mathrm{pg}$ per well with fixed amount of anti-MP1 or anti-spore protein antibody ( $2 \mu \mathrm{g}$ per well) as well as with fixed amount of antigen ( $10 \mu \mathrm{g}$ per well) and varying concentration of anti-MP1 or anti-spore antibody (10 $\mu$ to $100 \mathrm{pg}$ per well). In brief, the wells of 96 well ELISA plate (Thermo Scientific) were coated with $100 \mu \mathrm{L}$ of antigen diluted in coating buffer $(0.1 \mathrm{M}$ bicarbonate buffer $\mathrm{pH}$ 9.6) for overnight at $4{ }^{\circ} \mathrm{C}$. Wells were washed thrice with PBST ( 1 x PBS containing $0.05 \%$ Tween 20) and then blocked with $200 \mu \mathrm{L}$ of blocking buffer (PBST with $2 \% \mathrm{BSA}$ ) for $3 \mathrm{~h}$ at room temperature. Wells were washed thrice with PBST and then $100 \mu \mathrm{l}$ of anti-MP1 or anti-spore protein antibody diluted in PBST containing 1\% BSA was added and incubated at room temperature for $2 \mathrm{~h}$. The wells were then washed thrice with PBST, and $100 \mu$ of 1000-fold diluted secondary reagents (Protein-A HRP conjugate, GE Healthcare) was added and incubated at room temperature for $2 \mathrm{~h}$. The wells were washed again thrice with PBST and then color was developed using $100 \mu \mathrm{l}$ of 2,2'-azino-bis (3ethylbenzothiazoline-6-sulfonic acid) (ABTS) substrate $(0.5 \mathrm{mg} / \mathrm{ml}$, Sigma) prepared in $50 \mathrm{mM}$ citrate buffer, $\mathrm{pH} 5.0$ containing $\mathrm{H}_{2} \mathrm{O}_{2}$. Absorbance of the developed color was measured at $415 \mathrm{~nm}$ in a microplate ELISA reader (Thermo Scientific).

\section{Western blot analysis}

Western blot analysis was carried out following the protocol of Mahmood and Yang [19]. In brief, mycelial / spore / recombinant MP1 protein $(100 \mu \mathrm{g})$ were separated on 10\% SDS-PAGE and electroblotted onto nitrocellulose membrane using Mini trans-blot apparatus (Biorad) operated at $20 \mathrm{~V}$ for $14 \mathrm{~h}$ at room 
temperature. After the transfer, membranes were blocked with blocking buffer (PBST containing 3\% BSA) for 3 hrs at room temperature. Membrane was then washed thrice using PBST and treated with anti-MP1 or anti-spore protein antibody $(10 \mu \mathrm{g} / \mathrm{mL})$ in PBST containing $1 \%$ BSA for $3 \mathrm{~h}$ at room temperature. The membranes were then washed three times with PBST and further incubated with 1000-fold diluted secondary reagent (Protein-A HRP conjugate, GE Healthcare) in PBST containing 1\% BSA for $2 \mathrm{~h}$ at room temperature. After washing three times with PBST color was developed using Opti-4CN substrate (Biorad) or chemiluminescent substrates (Immobilon ${ }^{\circledR}$ forte HRP substrate, Millipore), and photographed in Chemi Doc system (Thermo scientific).

\section{Indirect immunofluorescence assay}

Mycelial and spore suspension of $A$. flavus $(1 \mathrm{ml})$ were prepared in $1 \times$ PBS, washed thrice and incubated in $500 \mu$ of blocking buffer (PBST with $3 \%$ BSA) for $2 \mathrm{~h}$ at $37{ }^{\circ} \mathrm{C}$ with gentle shaking. The blocking buffer was removed by centrifugation at $10,000 \mathrm{~g}$ for $1 \mathrm{~min}$ and the pellet was incubated with anti-MP1 or antispore protein antibody $(5 \mu \mathrm{g} / \mathrm{ml})$ for $1 \mathrm{~h}$ at $37^{\circ} \mathrm{C}$ with gentle shaking. Then, after washing with PBST three times, the pellets were resuspended and incubated with 1000-fold diluted FITC-conjugated antirabbit IgG (Sigma) for $1 \mathrm{~h}$ at room temperature in the dark. The unbound antibodies were removed by washing thrice with PBST, the pellets were resuspended in $1 \times$ PBS and the images of mycelia and spores were acquired using confocal microscope (Olympus).

\section{Analysis of antibody cross reactivity}

Cross reactivity of developed antibodies was tested by ELISA using mycelial lysate as antigen from fourteen different fungal species. Mycelial lysates of different fungi were prepared as described above and $100 \mu \mathrm{l}(1 \mu \mathrm{g}$ of protein) was used to coat each well of an ELISA plate. Anti-MP1 or anti-spore antibody ( $1 \mu \mathrm{g}$ per well), and 1000-fold diluted protein-A HRP conjugate (sigma) were used as primary antibody and secondary reagent, respectively. Colour was developed using ABTS as substrate in citrate buffer containing $\mathrm{H}_{2} \mathrm{O}_{2}$, and the absorbance of developed colour was measured at $415 \mathrm{~nm}$ in a microplate ELISA reader.

\section{Detection of $A$. flavus in contaminated wheat grains}

Wheat grains purchased from local market were washed thoroughly with distilled water and mixed with $100 \mathrm{mg}$ of freeze-dried A. flatus mycelia or $10^{7}$ spores per gram of wheat. Wheat grains were then crushed to fine powder using mortar and pestle in presence of liquid $\mathrm{N}_{2}$. The crushed powders were dissolved in 1 x PBS (pH 7.4), sonicated for $10 \mathrm{~min}$ and then centrifuged at 12,000 $\mathrm{g}$ for $15 \mathrm{~min}$. The supernatants were serially diluted in $0.1 \mathrm{M}$ bicarbonate buffer up to $10^{5}$ fold, and $100 \mu \mathrm{l}$ was used as antigen in ELISA using $1 \mu \mathrm{g}$ of anti-MP1 or anti-spore protein antibody (per well). Wheat grains without mixing with mycelia or spores were used as negative controls, and proteins extracted from mycelia and spores were used as positive controls during the assay. 


\section{Results}

\section{Preparation of $A$. flavus fungal spores and mycelia.}

A well characterized Aspergillus flavus isolate from stored wheat grain was cultivated on coconut agar media. This media specifically supported the formation of maximum number of fungal spores (Fig.1). Spores were first collected by washing the plates with PBS, and then fungal mycelia were obtained by scraping the surface of plates.

\section{Cloning and expression of $A$. flavus MP1 in E. coli.}

Total RNA was extracted from the collected $A$. flavus mycelia using TRIzol and converted to cDNA using cDNA synthesis kit. The MP1 cDNA was amplified by PCR, cloned in PTZ57 R/T vector and sequenced. BLAST search of the obtained sequence in Genbank databases showed $99 \%$ sequence similarity with the reported MP1 gene (gi|19716317|gb|AF461762.1) of A. flavus (Woo et al. 2003). The entire ORF (822 bp) of MP1 was then cloned in bacterial expression vector (pGEX4T-3 and pET28a) and recombinant GSTtagged and His-tagged soluble MP1 protein was purified using glutathione sepharsose and Ni-NTA affinity chromatography. SDS-PAGE analysis of purified GST-tagged MP1 protein showed one expected size $56 \mathrm{kDa}$ band (30 kDa MP1 protein tagged with $26 \mathrm{kDa}$ GST protein) along with another band of approximately $26 \mathrm{kDa}$ for GST (Fig. 2a, lane 4). Therefore, further purification of this protein was done through Q-sepharose column chromatography and elution profile from this column chromatography showed a single peak (Fig. S1), SDS-PAGE analysis of the protein purified by Q-sepharose column chromatography also showed two protein bands of around $56 \mathrm{kDa}$ and $26 \mathrm{kDa}$ (Fig. 2a, lane 5) indicating that in addition to GST-tagged fusion MP1 protein only GST protein is also produced in the recombinant bacteria. This is confirmed by western blot analysis using ant-GST antibody which showed reactivity with this $26 \mathrm{kDa}$ band strongly in addition to reactivity with $56 \mathrm{kDa}$ protein band (Fig. $\mathbf{2 b}$ lanes $\mathbf{4}$ and $\mathbf{5}$ ). The expression of $26 \mathrm{kDa}$ GST protein may be due to deletion of cloned Mp1 cDNA insert from some of the recombinant plasmid inside the bacteria during culture. SDS-PAGE analysis of purified recombinant Histagged MP1 protein showed a band of around $36 \mathrm{kDa}$, which was $6 \mathrm{kDa}$ more than the expected size (30 kDa) (Fig. 2c, lane 4). This may be due to presence of several extra amino acid sequences attached at the C-terminal end of MP1 cDNA during cloning in the expression vector pET28a. But the expression of recombinant His tagged MP1 protein was confirmed by its reactivity with anti-His antibody in western blot (Fig. 2d, lanes 3 and 4).

\section{Production of anti-Mp1 and anti-spore protein polyclonal antibodies}

Purified recombinant GST-tagged MP1 protein and formaldehyde inactivated fungal spores were injected subcutaneously in rabbit for antibody production. Both anti-MP1 specific and anti-spore protein specific polyclonal antibodies were purified from rabbit serum by three successive steps such as (a) ammonium sulphate precipitation of immunoglobulin, (b) IgG purification through protein-A sepharose affinity chromatography and (c) antigen affinity chromatography. SDS-PAGE analysis of both the antibodies showed presence of heavy chain and light chain protein bands (Fig. S2). The concentration of purified 
anti-MP1 antibody and anti-spore protein antibody was determined by Bradford assay as 1.2 and 0.85 mg per $\mathrm{ml}$, respectively.

\section{Detection of fungal Mp1 and spore proteins by ELISA and western blot}

The anti-MP1 and anti-spore protein polyclonal antibodies were used for the detection of $A$. flavus mycelia / spore / recombinant MP1 protein antigens by ELISA and western blot. During ELISA when different concentrations of above antigens $(100 \mu \mathrm{g}$ to $100 \mathrm{pg}$ per well) and a fixed concentration $(2 \mu \mathrm{g}$ per well) of anti-MP1 or anti-spore protein antibody were used, the results showed that minimum concentration of mycelial or spore proteins that could be detected for both the antibodies was $100 \mathrm{ng}$ (OD at $415 \mathrm{~nm}>0.1$ ) and then the values increased linearly up to $10 \mu \mathrm{g}$ of antigens (Fig. 3 a \& c).

Recombinant GST-tagged and His-tagged MP1 proteins were detected at concentration less than $10 \mathrm{ng}$. On the other hand when a fixed amount of these antigens (10 $\mu \mathrm{g}$ per well) and varying amount of antiMP1 or anti-spore protein antibodies (10 $\mu$ g to $100 \mathrm{pg}$ per well) were used the results showed that the minimum amount of these antibodies that is required for detection the antigenic proteins (OD at $415 \mathrm{~nm}$ $>0.1$ ) was $100 \mathrm{ng}$ per well and the intensity of developed colour increased increased linearly up to antibody concentration $1 \mu \mathrm{g}$ per well (Fig. 3 b \& d). Between these two antibodies, the anti-MP1 antibody was more sensitive than anti-spore protein for reacting with antigens at lower concentration.

Western blot analysis using anti-MP1 antibody showed reactivity with 36 kDa His-tagged recombinant MP1 protein (Fig. 4a, lane1) as well as 56 kDa GST-tagged MP1 protein (Fig. 4a, lane 2). This also confirmed that $36 \mathrm{kDa}$ His-tagged protein expressed in E. coli was recombinant MP1 although its size is 6 kDa larger than expected size (30 kDa). The anti-spore protein antibody reacted with different mycelial proteins (70 kDa to 100 kDa) (Fig. 4b, lane 1) of $A$. flavus as well as one 91 kDa spore protein (Fig. 4b, lane 2). The anti-MP1 antibody showed reactivity with several proteins ranging from 30 to $200 \mathrm{kDa}$ present in A. flavus mycelial and spore's proteins (Fig. 4c) indicating anti-MP1 antibody reacts not only with mycelia proteins but also cross react with spore protein. It is also possible that mycelia proteins are expressed on spore and vice versa. The immune fluorescence study also confirmed that both anti-MP1 and anti-spore antibody can react with the antigens present throughout the surface of mycelia as well as spores of $A$. flavus (Fig. 5a, b, c, d).

\section{Cross reactivity of $A$. flavus anti-Mp1 and anti-spore antibody with other fungi.}

The cross-reactivity of anti-MP1 and anti-spore antibody was tested against mycelial proteins extracted from fourteen different fungal isolates by ELISA. The results showed that the anti-MP1 antibody cross reacted with (O.D at $415 \mathrm{~nm}>0.1$ ) with $A$. niger, $A$. candidus, $A$. sydowii, Eurotium amstelodami, Alternaria alternate, Rhizopus oryzae, and Rhizopus microspore, whereas, anti-spore protein antibody showed cross reactivity with only Eurotium amstelodami, Alternaria alternate and Aspergillus sydowii (Fig. 6). Both the antibodies did not react with Talaromyces islandicus,Syncephalastrum racemosum, Westerdykella globose, Mucor circinelloides, Lichtheimia ramose, Penicillium cinnamopurpureum, Myceliophthora verrucose. 


\section{Assessment of $\boldsymbol{A}$. flavus contaminated wheat grains}

To detect $A$. flavus contamination in field samples, wheat grains (from local market) were mixed with dry fugal mycelia or spores, crushed and suspended in coating buffer. After centrifugation, supernatants were serially diluted and used as antigen in ELISA using anti-MP1 or anti-spore protein antibody. The results showed that both these antibodies can detect $A$. flavus in wheat grains contaminated (with OD value at $415 \mathrm{~nm}>0.1$ ) as low as $1 \mu \mathrm{g}$ mycelia or $10^{3}$ spores per gram of wheat (Fig. 7).

\section{Discussions}

In this study cell wall MP1 gene of $A$. flavus has been cloned and expressed in E. coli, and recombinant GST-tagged and His-tagged MP1 proteins have been purified. Polyclonal antibody has been raised against GST-tagged MP1 protein and purified by antigen (His-tagged MP1) affinity chromatography. In addition, anti-spore polyclonal antibody has been raised and purified. Using these antibodies, reactivity with mycelia, MP1 and spore proteins have been tested by ELISA, western blot and immunofluorescence assays. Among all these assays, ELISA has shown most sensitive in detecting these antigens. Using varying concentration of antigens and antibodies, it has been shown that as low as $100 \mathrm{ng}$ of MP1 and spore proteins may be detected using $100 \mathrm{ng}$ of antibodies. Among both these polyclonal antibodies, the anti-MP1 antibody has shown more sensitive for the detection of $A$. flavus contaminants (mycelial or spore protein) in wheat grains than anti-spore protein antibody indicating that the raised antibodies may be used to detect fungal contamination in wheat grains in storage facility.

Cross reactivity of anti-spore antibody with MP1 protein suggests the abundance of MP1 on fungal mycelia and spore surface. Mannoprotein is the most abundant fungal protein and accounts for $25 \%$ of the total fungal biomass, and can be solubilized from the cell surface easily by treating with reducing agents [20]. The mannoproteins have been used extensively for the detection on invasive aspergillosis $[21,22]$. Antibody against the proteins extracted from the mycelia of Fusarium graminearum and Fusarium moniliforme has shown reactivity with thirteen Fusarium fungi in addition to the producer strains. Polyclonal antibody developed against extracellular antigen from Aspergillus parasiticus showed cross reactivity with $A$. flavus. $A$. sojae and $A$. oryzae with the detection limit of $10^{3} \mathrm{cfu} / \mathrm{g}$ by ELISA [23]. Notermans et a1 [24] have shown strong antibody-antigen cross-reactions among Penicillium cyclopium, Penicillium digitatum, and Aspergillus repens. Tsai and Cousin [25] have reported that antibodies raised against Aspergillus versicolor reacted with not only many other Aspergillus species but also Penicillium urticae, Penicillium crustosum, and Penicillium italicum. Antibody cross-reactivity has also been reported in the immunological detection of pathogenic fungi from clinical isolates. Antisera raised against extracts of Aspergillus fumigatus have shown variable cross-reactivity with $A$. flavus, $A$. nidulans, $A$. niger, and $A$. terreus $[26,27]$. Monoclonal antibodies against $A$. fumigatus galactomannan also have shown reactivity with the other Aspergillus fungi. These results indicate that similar antigenic epitopes may be present among Aspergillus fumigatus, Penicillium, Trichoderma rubrum, Trichophyton interdigitalis, and Botrytis tulipae. In the present study, the raised anti-MP1 and anti-spore antibody of $A$. flavus have shown detectable cross-reactivity mainly with the fungus belonging to the Aspergillus, Rhizopus and Alternaria 
genus and indicates that the raised antibodies may be used to detect not only Aspergillus species but other fungal contamination also.

Sensitivity and specificity are mostly considered during the development of immunological detection method. In that respect monoclonal antibody is more specific and highly selective as it reacts with a single epitope of an antigen but polyclonal antibody is advantageous for high sensitivity by reacting with multiple epitopes of antigen [28]. The developed polyclonal antibodies against MP1 and spore proteins showed very high sensitivity with marginal selectivity but it could be advantageous for the detection of overall fungal contaminants present in stored grains. The sensitivity of the developed ELISA with these antibodies can be further enhanced with proper solubilisation of antigenic proteins from the fungal mycelia or spores in the contaminated food grains by the addition of chitinase and $\beta-1,3$ glucanase enzymes in the solubilization buffer followed by sonication. Overall, the developed ELISA based immunological method will be useful in screening presence of a wide range of fungal infection in food grains before its distribution for consumption.

\section{Conclusion}

Direct ELISA was developed by raising polyclonal antibody against $A$. flavus mannoprotein (MP1) and spore proteins for the detection fungal infestation in stored wheat grains. The specificity and sensitivity of development ELISA method was tested by analysing fourteen different fungal species. The crossreactivity study in ELISA and western blot indicates presence of common antigenic proteins in different fungal isolates. The developed direct ELISA using anti-MP1 antibody is more sensitive than anti-spore protein antibody and can be used for the assessment of different fungal contaminants especially aflatoxigenic fungi present in wheat grains during storage condition.

\section{Declarations}

Acknowledgements This work was supported by a grant from Ministry of Human resource Development, Government of India. Ranjana Kumari is the recipient of fellowship from the Department of Biotechnology, Government of India.

Authors' contributions Ranjana Kumari designed. performed all the experiments and wrote the manuscript. Ananta Kumar Ghosh conceived, brought funding, supervised, reviewed and edited the manuscript. Both the authors read and approved the manuscript.

\section{Compliance with ethical standards}

Competing Interests The authors declare that they have no known competing financial interests.

Availability of data and materials Not applicable 
Ethical approval: Animal experimentation has been done after receiving the approval of Institutional Animal Ethical Committee. Other ethical approval is not applicable.

Consent to participate All authors provides consent to participate in the manuscript.

Consent to publish All authors have given consent to publish the manuscript

\section{References}

1. Birck, N. M. M., Lorini, I., \& Scussel, V. M. (2006). In: Proceedings of the 9th international working conference on stored-product protection. Brazilian Post-Harvest Association (Lorini, I. et al., eds) PP 193-197. (http://spiru.cgahr.ksu.edu/proj/iwcspp/pdf2/9/6285.pdf)

2. Tournas, V. H., \& Niazi, N. S (2018). Journal of Food Safety, 38, 1-6. https://doi.org/10.1111/jfs.12422.

3. Schmidt, M., Zannini, E., \& Arendt, E. K. (2018). Foods, 7(4), https://doi.org/10.3390/foods7040045.

4. Hyde, K. D., Xu, J., Rapior, S., Jeewon, R., Lumyong, S., \& Niego, A. G. T. (2019). Fungal Diversity, 97, 1-136. https://doi.org/10.1007/s13225-019-00430-9.

5. Sohbatzadeh, F., Mirzanejhad, S., Shokri, H. \& Nikpour, M. (2016). Journal of the Theoretical and Applied Physics. 10, 99-106. https://doi.org/10.1007/s40094-016-0206-z.

6. Aldars-García, L., Marín, S., Sanc-His, V., Magan, N., \& Medina, A. (2018). International Journal of Food Microbiology, 272, 1-11. https://doi.org/10.1016/j.ijfoodmicro.2018.02.016.

7. Amaike, S., \& Keller, N. P. (2011). Annual Review of Phytopathology, 49, 107-33. https://doi.org/10.1146/annurev-phyto-072910-095221.

8. Gourama, H., \& Bullerman, L. B. (1995). Journal of Food Protection, 58(12), 1389-1394. http://doi.org/10.4315/0362-028X-58.12.1389.

9. Darling, J. A., \& Blum, M. J. (2007). Biological Invasions, 9, 751-765. https://doi.org/10.1007/s10530006-9079-4.

10. Dewey, F. M., Twiddy, D. R., Phillips, S. I., Grose, M. J., \& Wareing, P. W. (1992). Food and Agricultural Immunology, 4(3), 153-167. https://doi.org/10.1080/09540109209354764.

11. Banks, J. N., Cox, S. J., Northway, B. J., \& Rizvi, R. H. (1994). Food and Agricultural Immunology., 6(3), 321-327. https://doi.org/10.1080/09540109409354844.

12. Lu, P., Marquardt, R. R., Frohlich, A. A., \& Mills, J. T. (1995). Food and Agricultural Immunology, 7(1), 81-93. https://doi.org/10.1080/09540109509354867.

13. Notermans, S., \& Heuvelman, C. J. (1985). International Journal of Food Microbiology, 2, 247-258. https://doi.org/10.1016/0168-1605(85)90015-7.

14. Notermans, S., Heuvelman, C.J., Van Egmond, H.P., Paulsch, W.E., \& Besling, J.R. (1986). Journal of Food Protection, 49(10), 786-791. https://doi.org/10.4315/0362-028X-49.10.786. 
15. Woo, P. C. Y., Chong, K. T. K., Leung, A. S. P., Wong, S. S. Y., Lau, S. K. P., \& Yuen, K. Y. (2003). Journal of Clinical Microbiology, 41, 845-850. https://doi.org/10.1128/JCM.41.2.845-850.2003.

16. Kumari, R., Jayachandran, L. E., \& Ghosh, A. K. (2019). Journal of the Science Food and Agriculture, 99(7), 3490-3500. https://doi.org/10.1002/jsfa.9568.

17. Bradford, M. M., (1976). Analytical Biochemistry, 72, 248- https://doi.org/10.1006/abio.1976.9999.

18. Harlow, E. D., \& Lane, D. (2014). Antibodies: A laboratory manual. Second Edition, Cold Spring Harbor Laboratory Press, New York.

19. Mahmood, T., \& Yang, P. C. (2012). Journal of Medical Science, 4(9), 429-434. http://doi.org/10.4103/1947-2714.100998.

20. Cao, L., Chan, K. M., Chen, D., Vanittanakom, N., Lee, C., Chan, C. M., \& Yuen, K.Y. (1999). Journal of Clinical Microbiology, 37(4), 981-986. https://doi.org/10.1128/JCM.37.4.981-986.1999.

21. Wang, Z. Y., Cai, J. P., Qiu, L.W., Hao, W., Pan, Y. X., Tung, E. T. K., Lau, C. C. Y., Woo, P. C. Y., Lau, S. K. P., Yuen, K-Y., \& Che, X-Y. (2012). European Journal of Clinical Microbiology and Infectious Disease, 31(11), 2943-2950. https://doi.org/10.1007/s10096-012-1645-3.

22. Iyer, M. S., \& Cousin, M. A. (2003). Journal of Food Protection, 66(3), 451-456. https://doi.org/10.4315/0362-028x-66.3.451.

23. Yong, R. K., \& Cousin, M. A., (2001). International Journal of Food Microbiology, 65(1-2), 27-38. https://doi.org/10.1016/s0168-1605(00)00505-5.

24. Notermans, S. G., Wieten, H. W. B., Engel, F. M., Rombouts, P., \& Hoogerhout, J. H. (1987). Journal of Applied Bacteriology, 62, 157-166. https://doi.org/10.1111/j.1365-2672.1987.tb02394.x.

25. Tsai, G.-J., \& Cousin, M. A., (1990). Journal of Dairy Science, 73, 3366-3378. https://doi.org/10.3168/jds.S0022-0302(90)79032-7.

26. Kaufman, L., \& Standard, P. G., (1987). Annual Review of Microbiology, 41(1), 209-225. https://doi.org/10.1146/annurev.mi.41.100187.001233.

27. Stynen, D., Sarfati, J., Goris, A., Prevost, M. C., Lesourd, M., Kamphuis, H., Darras, V., \& Latge, J. P., (1992). Infection and Immunity, 60(6), 2237-2245. https://doi.org/iai.asm.org.

28. Lipman, N. S., Jackson, L. R., Trudel, L. J., \& Weis-Garcia, F., (2005). Journal of Institute Laboratory Animal Research, 46(3), 258-268. https:// doi.org/101093/ilar.46.3.258.

\section{Figures}




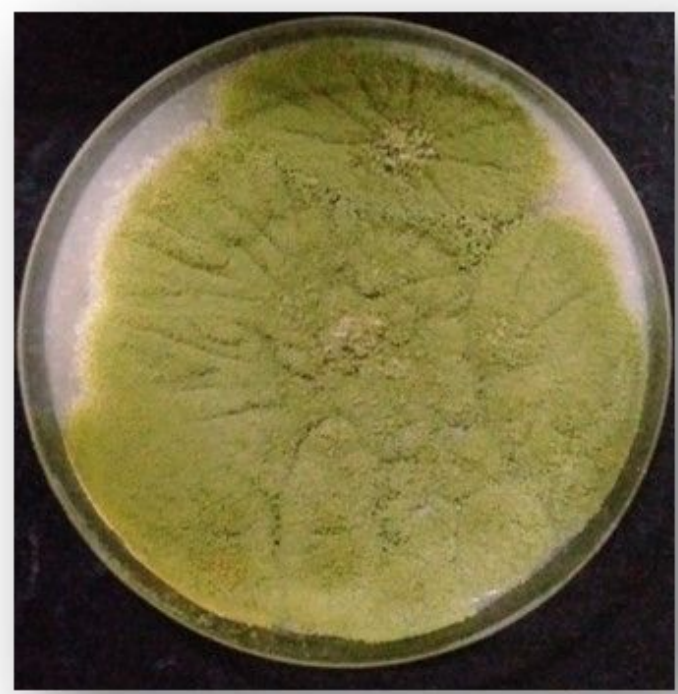

(a)

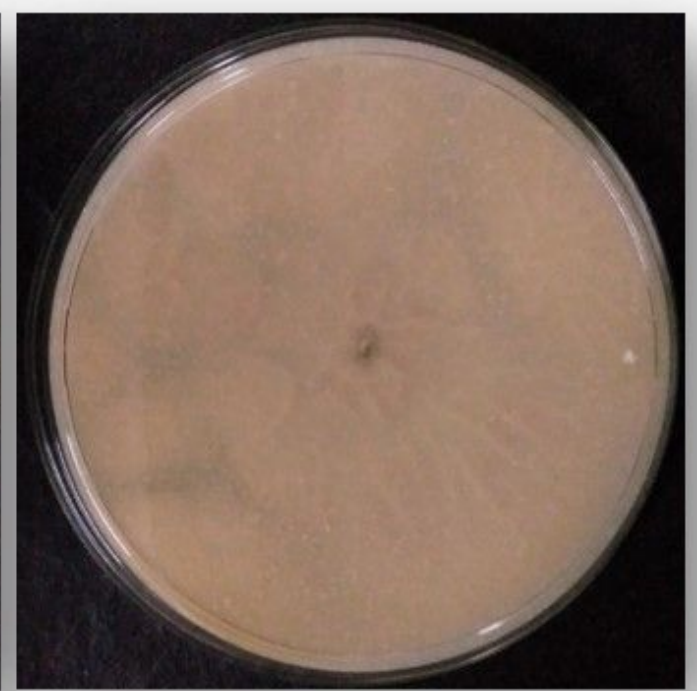

(b)

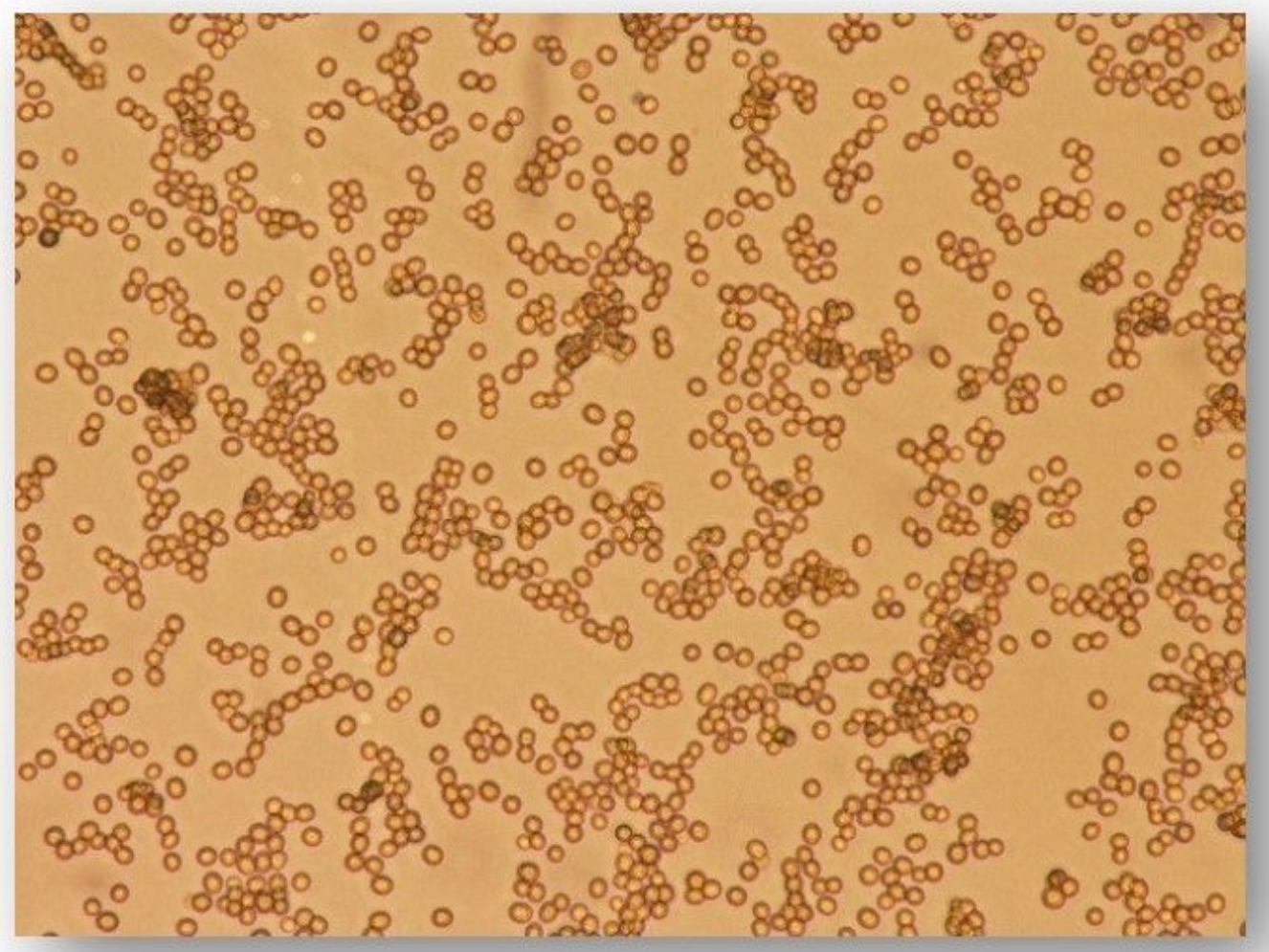

(c)

\section{Figure 1}

Morphology of A. flavus isolate and its spores. Front (a) and reverse (b) view of A. flavus grown on coconut agar media plate. (c) Light microscopic view of isolated spores from the same fungus (magnification $400 \mathrm{X}$ ). 


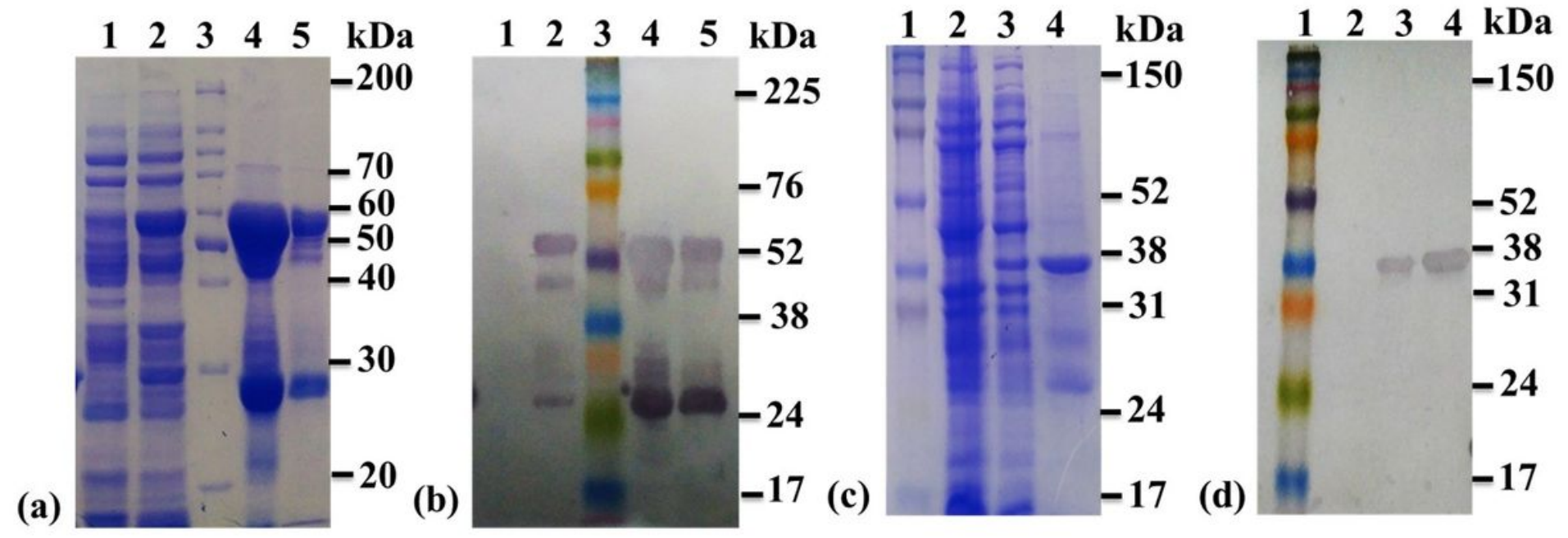

Figure 2

Expression of recombinant MP1 protein in E. coli. (a) SDS-PAGE analysis of recombinant GST-tagged MP1 protein. Lane 1, uninduced E. coli lysate; lane 2, IPTG induced E. coli lysate; lane 3, protein molecular weight marker; lane 4, GST-tagged MP1 protein purified through glutathione sepharaose affinity chromatography; lane 5, GST-tagged MP1 protein purified through anion exchange (Q-sepharose) chromatography; (b) Western blot image of the same gel (a) using anti-GST antibody, (c) SDS-PAGE analysis of recombinant His-tagged MP1 protein. lane 1, protein molecular weight marker; lane 2, uninduced E. coli lysate; lane 3, IPTG induced E. coli lysate; lane 4, His-tagged MP1 protein purified through Ni-NTA affinity chromatography, (d) western blot image of the same gel (c) using anti-His antibody. Sizes of proteins in kDa are shown in right. 

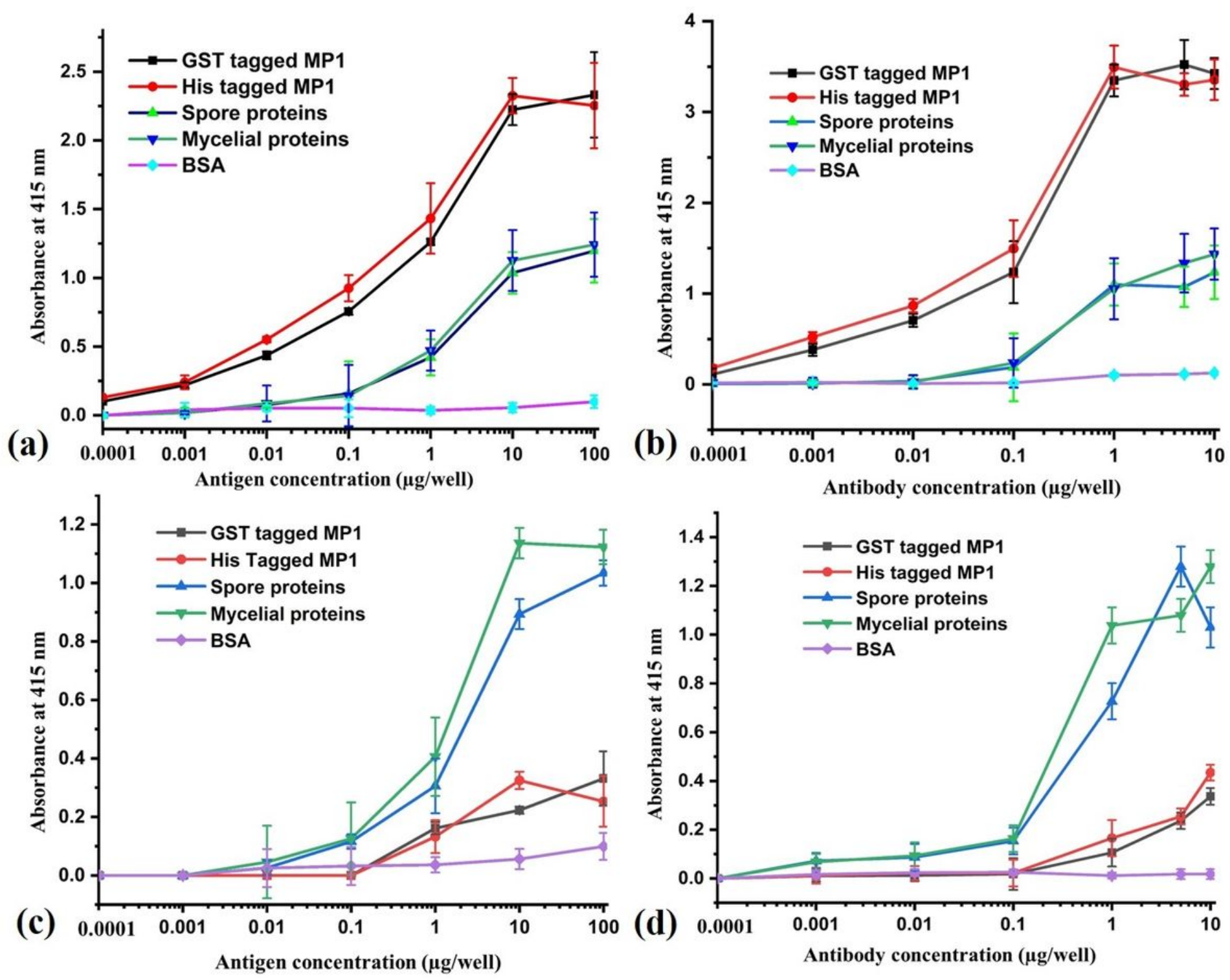

Figure 3

ELISA using varying concentration of different antigens and antibodies. (a) ELISA using fixed amount of anti-MP1 antibody (2 ug per well) with varying concentration of different antigens. (b) ELISA using fixed amounts of different antigens (10 ug per well) with varying concentration of anti-MP1 antibody. (c) ELISA using fixed amount of anti-spore antibody $(2 \mu \mathrm{g}$ per well) with varying concentration of different antigens. (d) ELISA using fixed amounts of different antigens ( $10 \mu \mathrm{g}$ per well) with varying concentration of antispore antibody. Values in each point represent mean \pm standard deviation of triplicate experiments. 

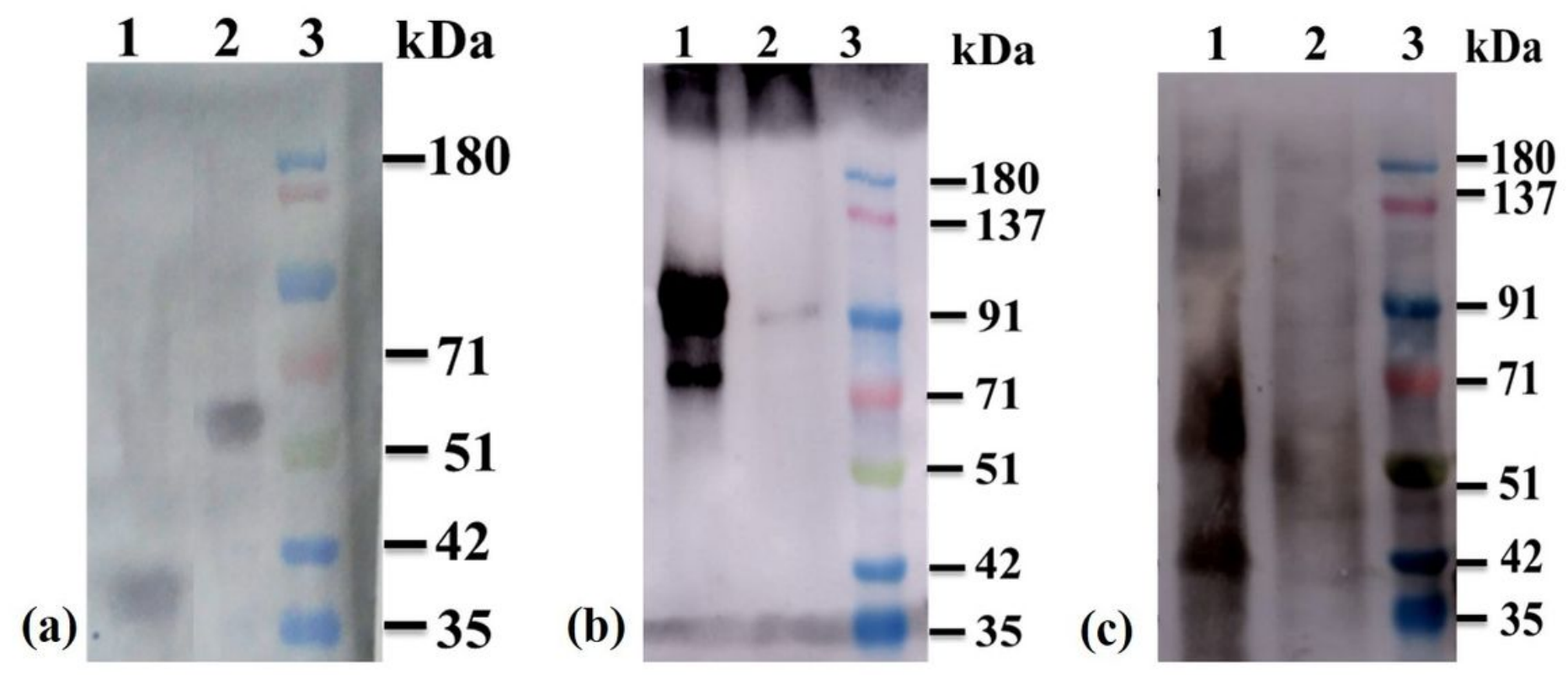

\section{Figure 4}

Western blot analysis. (a) Reactivity of anti-MP1 antibody with E. coli expressed recombinant proteins. Lane 1, purified His-tagged MP1 protein; lane 2, purified GST tagged MP1 protein; lane 3, Pre-stained protein molecular weight marker. (b) Reactivity of anti-spore protein antibody with A. flavus mycelial and spore lysate. Lane 1, mycelial proteins; lane 2, spore proteins; lane 3, pre stained protein molecular weight marker; (c) Reactivity of anti-MP1 antibody with A. flavus mycelial and spore lysate. Lane 1, mycelial proteins; lane 2, spore proteins; Lane 3, pre stained protein molecular weight marker. Sizes of proteins in $\mathrm{kDa}$ are shown in right. 


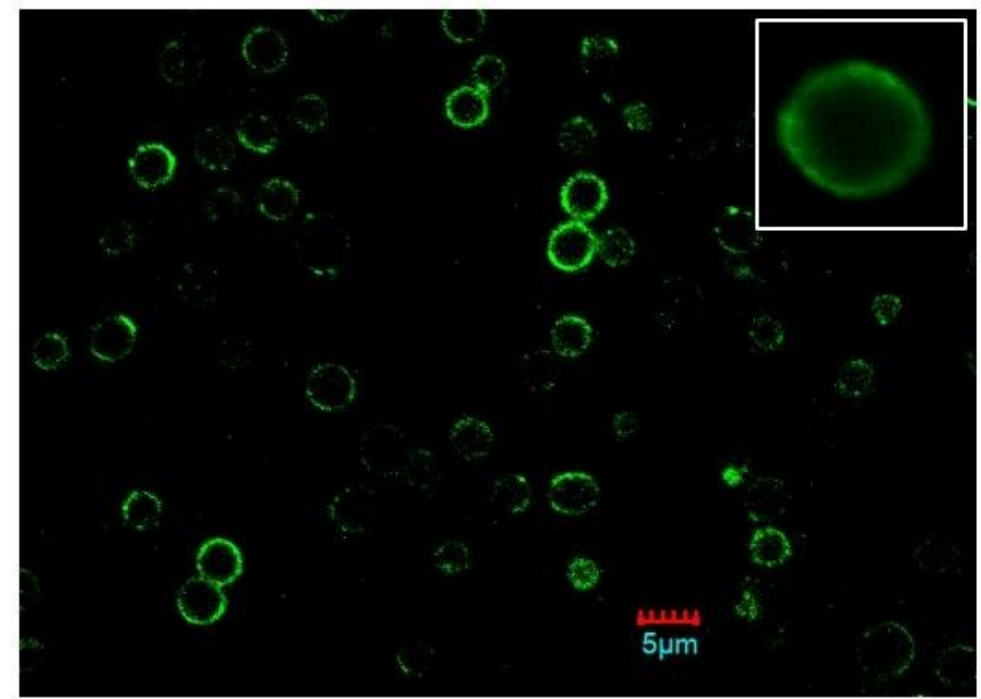

\section{(a)}

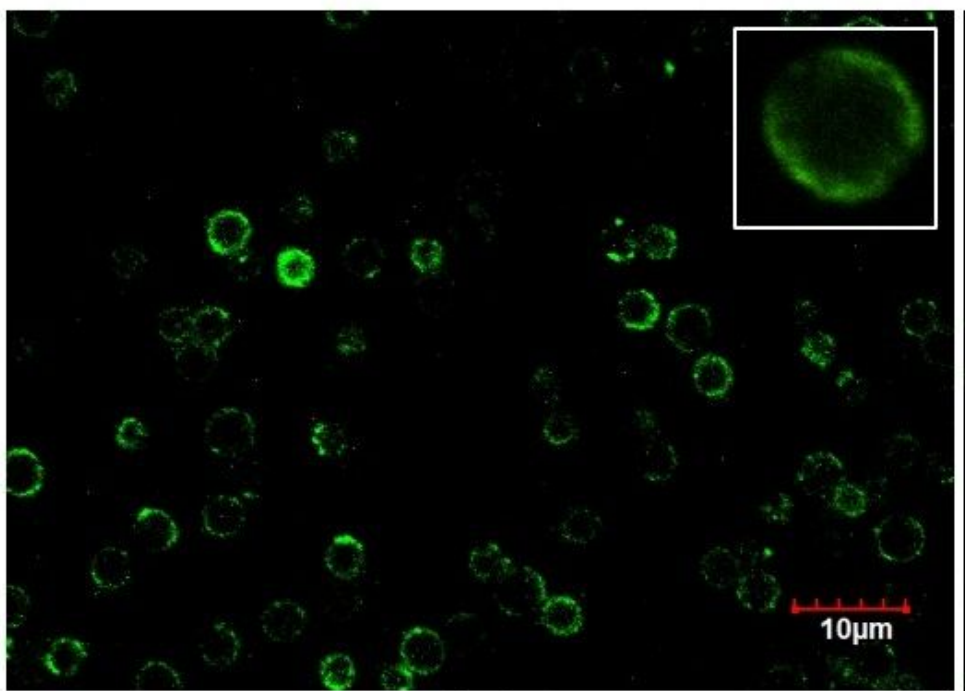

(c)

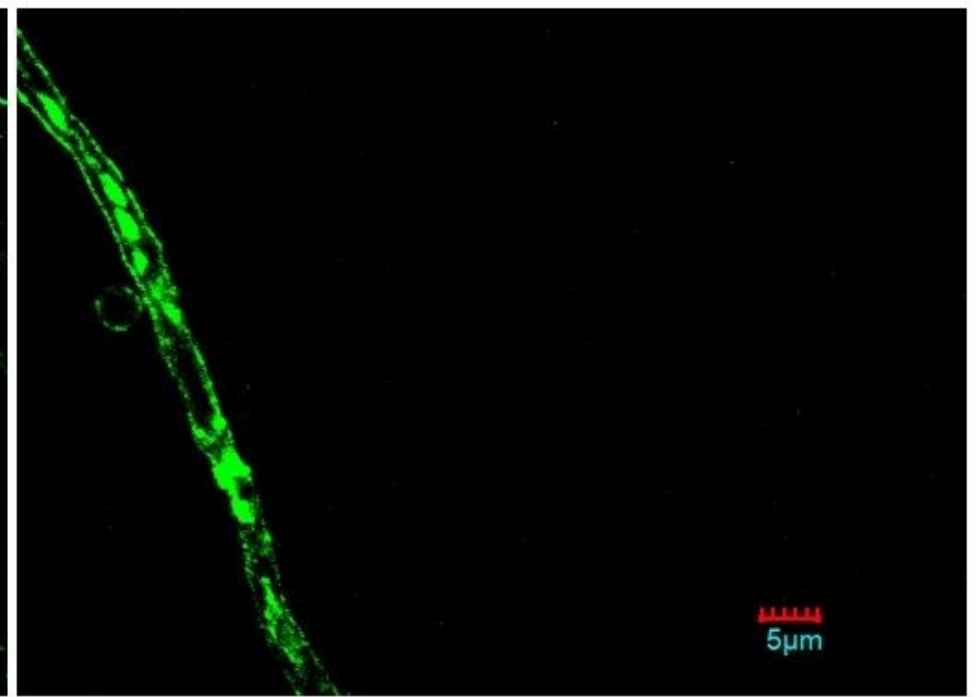

(b)

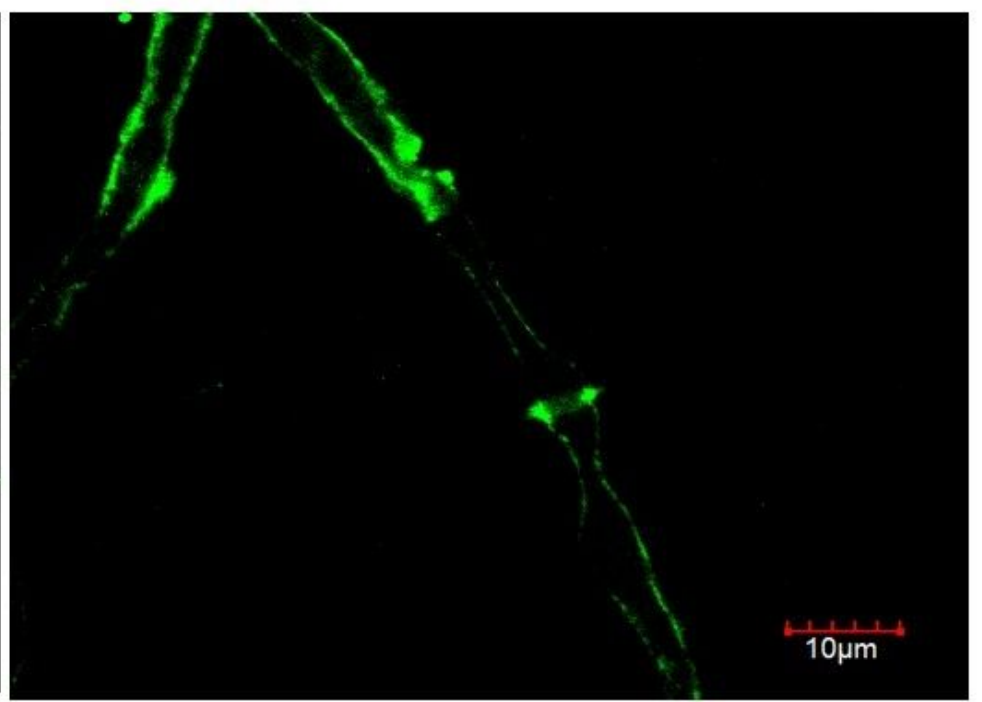

(d)

\section{Figure 5}

Immunofluorescence analysis of A. flavus mycelia and spores. Fluorescence microscopic images A. flavus spores after staining with FITC conjugated anti-MP1 (a) and anti-spore (c) antibody. Inset shows enlarged view of single spore. Fluorescence microscopic images A. flavus mycelia after staining with FITC conjugated anti-Mp1 (b) and anti-spore (d). 


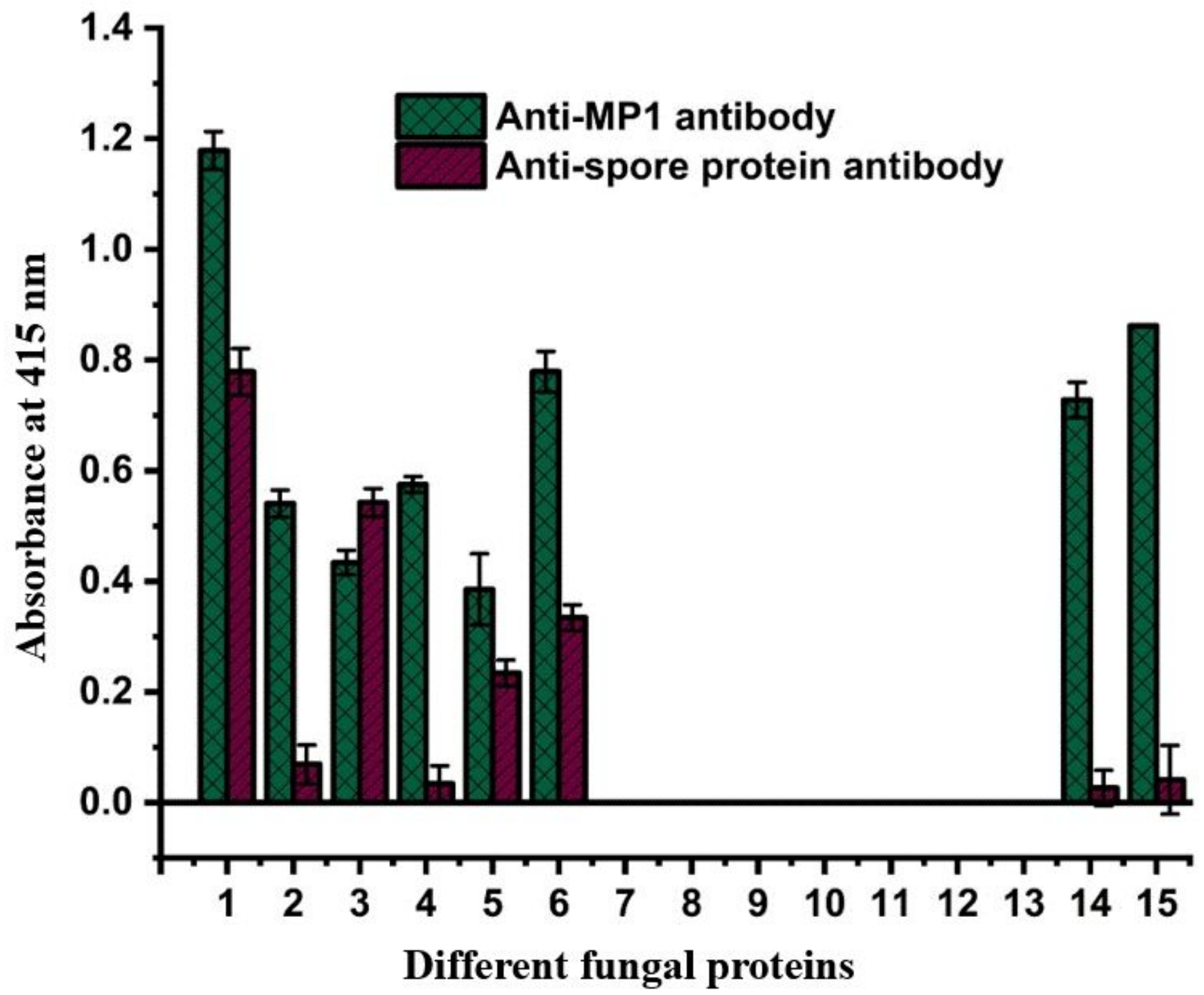

Figure 6

Cross reactivity analysis of anti-MP1 and anti-spore antibody against fourteen different fungal species by ELISA 1, Aspergillus flavus; 2, Aspergillus niger; 3, Eurotium amstelodami; 4, Aspergillus candidus; 5 , Aspergillus sydowii; 6, Alternaria alternate; 7, Talaromyces islandicus, 8, Syncephalastrum racemosum; 9 , Westerdykella globose; 10, Mucor circinelloides; 11, Lichtheimia ramose; 12, Penicillium cinnamopurpureum; 13, Myceliophthora verrucose;14, Rhizopus microspores; 15, Rhizopus oryzae. Value in each bar represents mean \pm standard deviation of triplicate experiments. 

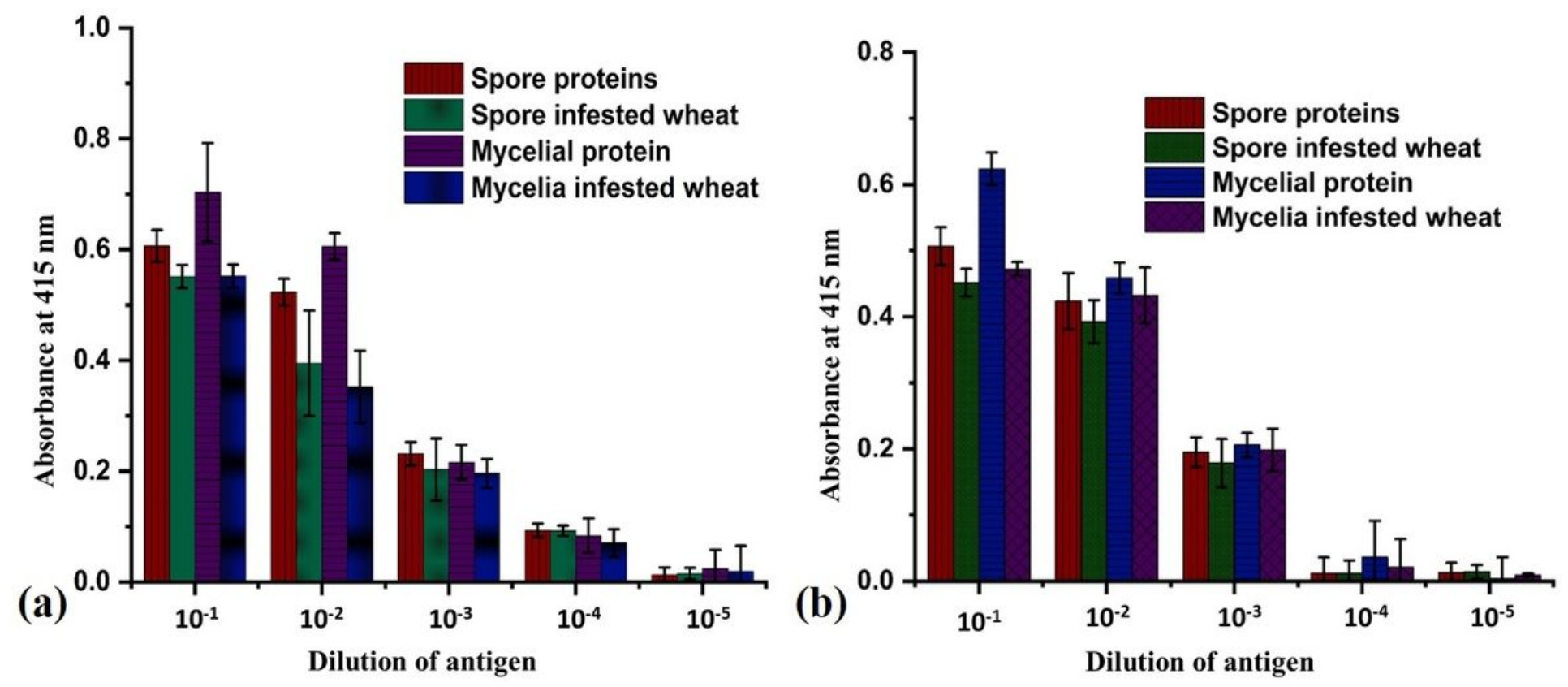

Figure 7

Detection of A. flavus contamination (mycelia and spores) in wheat grains by ELISA using (a) anti-MP1 and (b) anti-spore protein antibody. Value in each bar represents mean \pm standard deviation of triplicate experiments.

\section{Supplementary Files}

This is a list of supplementary files associated with this preprint. Click to download.

- Supplementaryinformation.pdf 